Article

\title{
The Role of Insulin-Like Growth Factor-2 on the Cellular Viability and Differentiation to the Osteogenic Lineage and Mineralization of Stem Cells Cultured on Deproteinized Bovine Bone Mineral
}

\author{
Hyunjin Lee ${ }^{1,+}+$, , Sae Kyung Min ${ }^{1,+}$, Yoon-Hee Park ${ }^{2}$ and Jun-Beom Park ${ }^{1, *} \mathbb{C}$ \\ 1 Department of Periodontics, College of Medicine, The Catholic University of Korea, Seoul 06591, Korea; \\ hyunjinlee0423@gmail.com (H.L.); msek1004@naver.com (S.K.M.) \\ 2 ebiogen, Seoul 07282, Korea; yhpark@e-biogen.com \\ * Correspondence: jbassoon@catholic.ac.kr; Tel.: +82-2-2258-6290 \\ + Hyunjin Lee and Sae Kyung Min contributed equally.
}

Received: 26 June 2020; Accepted: 5 August 2020; Published: 7 August 2020

\begin{abstract}
Insulin-like growth factors (IGFs) plays various roles, including differentiation and mitogenesis, and IGFs are reported to regulate the bone growth and maintenance. This study was performed to analyze the enhancing effects of IGF-2 on osteogenic differentiation and the mineralization of stem cells cultured on deproteinized bovine bone mineral. Stem cell loaded bone graft material was cultured in the presence of the IGF-2 at final concentrations of 10 and $100 \mathrm{ng} / \mathrm{mL}$ and the morphology of the cells was observed on Days 1,3, and 7. The commercially available, two-color assay based on plasma membrane integrity and esterase activity was also used for qualitative analyses on Days 1, 3, and 7. The level of alkaline phosphatase activity and anthraquinone dye assay were used to evaluate osteogenic differentiation on Days 7 and 14. Real-time polymerase chain reaction was applied in order to identify the mRNA expression of BGLAP, Runx2, and $\beta$-catenin. The stem cells were well-attached with fibroblast morphology and most of the stem cells produced a high intensity of green fluorescence, indicating that there were live cells on Day 1 . The relative cellular viability assay values for IGF- 2 groups at 0,10 , and $100 \mathrm{ng} / \mathrm{mL}$ on Day 1 were $0.419 \pm 0.015$, $0.427 \pm 0.013$, and $0.500 \pm 0.030$, respectively $(p<0.05)$. The absorbance values at $405 \mathrm{~nm}$ for alkaline phosphatase activity on Day 7 for IGF-2 at 0, 10, and $100 \mathrm{ng} / \mathrm{mL}$ were $2.112 \pm 0.152,1.897 \pm 0.144$, and $2.067 \pm 0.128$, respectively $(p>0.05)$. The mineralization assay results at Day 7 showed significantly higher values for IGF-2 groups at 10 and $100 \mathrm{ng} / \mathrm{mL}$ concentration when compared to the control $(p<0.05)$. The application of IGF-2 groups of 10 and $100 \mathrm{ng} / \mathrm{mL}$ produced a significant increase of BGLAP. Conclusively, this study indicates that the use of IGF-2 on stem cell loaded bone graft increased cellular viability, Alizarin red staining, and BGLAP expression of stem cells. This report suggests the combined approach of stem cells and IGF-2 with scaffold may have synergistic effects on osteogenesis.
\end{abstract}

Keywords: bone marrow; cell survival; cell differentiation; insulin-like growth factor II; osteogenesis; stem cells

\section{Introduction}

Bone loss is caused by various causes, such as infection, deterioration of function due to aging, trauma, cyst, and tumor in oral and maxillofacial areas [1]. The method of grafting autogenous or allogenic bone in order to enhance esthetic, functional recovery, stability, and healing has long been applied to clinical practices and it is still widely used today [2]. Grafting materials require strength that 
is similar to bone, biocompatibility that does not cause immune or inflammatory reactions, absorbability so they can be appropriately replaced by regenerated tissues, and radiopacity if applicable [3]. Recently, greater interest has been given to the bone graft material that can replace autogenous or allogenic bone to recover or reconstruct the defect area [4]. Many successful results are being reported regarding the use of deproteinized bovine bone in oral and maxillofacial surgery [5].

Increasing interest had been put on the use of stem cells in tissue regeneration [6]. A previous report showed that the combined use of adult stem cells and scaffolds enhanced bone regeneration in rabbit models [7]. Cell therapy applying mesenchymal stem cells with osteoinductive/osteoconductive scaffold has been used in clinical practices, including sinus augmentation procedures [8]. Moreover, combinatorial effect of stem cells and growth factor was tested in previous researches [9,10]. Additionally, it was suggested that mesenchymal stem cells can be combined with bone morphogenetic protein-2 to enhance bone formation in early healing period [10]. Insulin-like growth factors (IGFs) control various functions, including differentiation and mitogenesis, and IGFs are reported to regulate the bone growth and maintenance [11]. It was reported that IGF-2 modulated both osteoblast formation and osteoblast-osteoclast interactions [12]. IGF-2 was suggested to be involved in enhancement of the early osteogenic marker of alkaline phosphatase activity and later markers [13]. This study was performed in order to evaluate the enhancing effects of IGF-2 on osteogenic differentiation and mineralization of stem cells cultured on deproteinized bovine bone mineral.

\section{Materials and Methods}

\subsection{Culturing of Bone Marrow Mesenchymal Stem Cells on Bone}

The approval of the present study was given by the Institutional Review Board of Seoul St Mary's Hospital (KC20SISI0333). All of the experimental schemes used were carried out based on the relevant guidelines. Human bone marrow-derived mesenchymal stem cells (BMSCs; Catholic MASTER cells) were acquired from the Catholic Institute of Cell Therapy (CIC, Seoul, Korea) [14,15]. CIC verified that all of the samples showed $>90 \%$ positive CD 73 and CD 90 expression.

Figure 1 indicates an overview of the study design. The stem cells were loaded onto the bone graft material (Geistlich Bio-Oss ${ }^{\circledR}$, Geistlich Pharma AG, Wolhusen, Switzerland) and then incubated in the media. The media consist of $\alpha$-minimum essential medium (MEM; Gibco; Thermo Fisher Scientific, Inc., Waltham, MA, USA), fetal bovine serum (15\%; Gibco), and penicillin-streptomycin (100 U/mL and 100 mg/mL; Sigma-Aldrich; Merck KGaA, St. Louis, MO, USA). Stem cell-loaded graft was cultured in the presence of the IGF-2 at final concentrations of 0, 10, and $100 \mathrm{ng} / \mathrm{mL}$ [16].
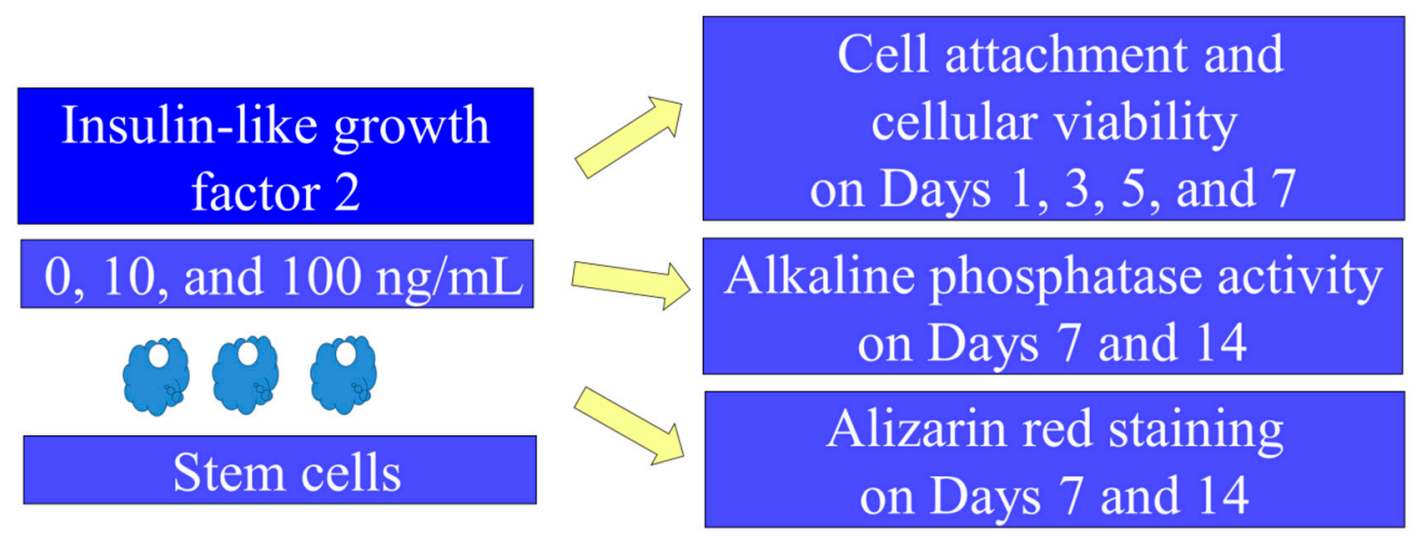

Figure 1. Overview of study design.

\subsection{Morphologic Evaluation of Stem Cells}

The morphological characteristics of the stem cells on the bone graft material was observed on Days 1,3,5, and 7. The culture media was then removed and the cells on the graft material were gently 
washed with phosphate-buffered saline. After fixation of the stem cells with $4 \%$ paraformaldehyde (Biosesang, Seongnam-si, Korea) at ambient temperature for $20 \mathrm{~min}$. , the cells on the bone graft material were rinsed three times with Dulbecco's phosphate-buffered saline solution. The cells were then stained using a $1 \times$ Phalloidin conjugate working solution for $60 \mathrm{~min}$. at room temperature; a $1 \times$ Phalloidin conjugate working solution can be made from $1 \mu \mathrm{L}$ 1000× Phalloidin conjugate stock solution (ab235138, Abcam) and $1 \mathrm{~mL}$ of 1\% BSA in phosphate-buffered saline. Small drop volumes (approximately $25 \mu \mathrm{L}$ ) of mounting medium containing nuclear stain (Vectashield, VECTOR laboratories, Burlingame, CA, USA) were applied to the cells and the stem loaded bone grafts were observed using a microscope.

\subsection{Determination of Cellular Viability}

We used the commercially available two-color assay based on plasma membrane integrity and esterase activity (Live/Dead Kit assay, Molecular Probes, Eugene, OR, USA) for qualitative analysis of the stem cells that were cultured on the bone graft material on Days 1 and 7. The media was removed and then suspended in $1 \mathrm{~mL}$ of Dulbecco's phosphate-buffered saline working solution (containing $2 \mu \mathrm{L}$ of $2 \mathrm{mM}$ ethidium homodimer- 1 and $0.5 \mu \mathrm{L}$ of $4 \mathrm{mM}$ calcein acetoxy methyl ester) for $1 \mathrm{~h}$ at room temperature. We also performed a quantitative cellular viability test using an assay kit based on the water-soluble tetrazolium salt (Cell Counting Kit-8, Dojindo, Tokyo, Japan) on Days 1, 3, 5, and 7.

\subsection{Level of Alkaline Phosphatase Activity and Calcium Deposition}

The level of alkaline phosphatase activity was analyzed in order to evaluate the differentiation to osteogenic lineage on Days 7 and 14 (K412-500, BioVision, Inc., Milpitas, CA, USA). The cells on the bone mineral particle were re-suspended with an assay buffer, then decomposed with triton X-100, and then centrifuged to eliminate insoluble material. We incubated the mixture for $60 \mathrm{~min}$ at $4{ }^{\circ} \mathrm{C}$ after mixing the supernatant with the substrate. Subsequently, we measured the spectrophotometric absorbance at $405 \mathrm{~nm}$.

We used an anthraquinone dye assay for calcium deposit evaluation on Days 7 and 14 to assess the osteogenic differentiation. After washing and fixation procedures, we stained the stem cells on the bone graft with 2\% Alizarin-Red Solution (ScienCell Research Laboratories, Inc., Carlsbad, CA, USA) for $20 \mathrm{~min}$. at room temperature. Ten percent cetylpyridinium chloride (Sigma-Aldrich Co.) solution was applied for $15 \mathrm{~min}$ at ambient temperature to solubilized the bound dye. We measured the spectrophotometric absorbance at $560 \mathrm{~nm}$ to perform the quantification of the bound dyes.

\section{5. mRNA Quantification by Real-Time Polymerase Chain Reaction}

We harvested the cells on Day 7 and isolated total RNA using purification kit (Thermo Fisher Scientific, Inc.), following the manufacturer's instructions [17]. RNA quality was assessed with a bioanalyzer (Agilent 2100, Agilent Technologies) using the kit (RNA 6000 Nano Chip; Agilent Technologies, Amstelveen, The Netherlands), and the quantity was performed using the spectrophotometer (ND-2000, Thermo Fisher Scientific, Inc.) with a ratio of absorbance at $260 \mathrm{~nm}$ and $280 \mathrm{~nm}$ spectrophotometrically. We used RNA as a template for reverse transcription while using the reverse transcriptase (SuperScript II; Invitrogen, Carlsbad, CA, USA).

We detected mRNA expression by real-time polymerase chain reaction (PCR). We used GenBank to designe the sense and antisense primers. The primer sequences were as follows: bone gamma-carboxyglutamate protein (BGLAP) (forward: 5'-AATCCGGACTGTGACGAGTT-3', reverse: 5'-CAGCAGAGCGACACCCTAGA-3'), Runx2 (forward: 5'-CAGTTCCCAAGCATTTCATCC-3', reverse: $5^{\prime}$ - AGGTGGCTGGATAGTGCATT- ${ }^{\prime}$ ), and $\beta$-actin (forward: $5^{\prime}$-AATGCTTCTAGGC GGACTATGA-3', reverse: $5^{\prime}$-TTTCTGCGCAAGTTAGGTTTT-3'). Normalization was performed by applying $\beta$-actin as a housekeeping gene. Real-time PCR was performed using SYBR Green PCR Kit (Applied Biosystems, Waltham, MA, USA) on the PCR System (StepOnePlus ${ }^{\mathrm{TM}}$; Applied Biosystems), according to the manufacturer's instructions. 


\subsection{Statistical Analysis}

All of the statistical analyses were performed using the software (SPSS 12 for Windows, SPSS Inc., Chicago, IL, USA) via one-way analysis of variance followed by Tukey's post hoc test after conducting a test of normality and the equality of variances of the samples. Three experimental repeats were evaluated for the analysis. All of the results values were presented as mean \pm standard deviation with the level of significance at 0.05 .

\section{Results}

\subsection{Morphologic Evaluation and Cellular Viability of Stem Cells}

The stem cells were well-attached with fibroblast morphology at Day 1 (Figure 2). Adding IGF-2 did not produce significant changes. The morphology of the cells with longer incubation showed a similar shape of fibroblast (Figure 2).
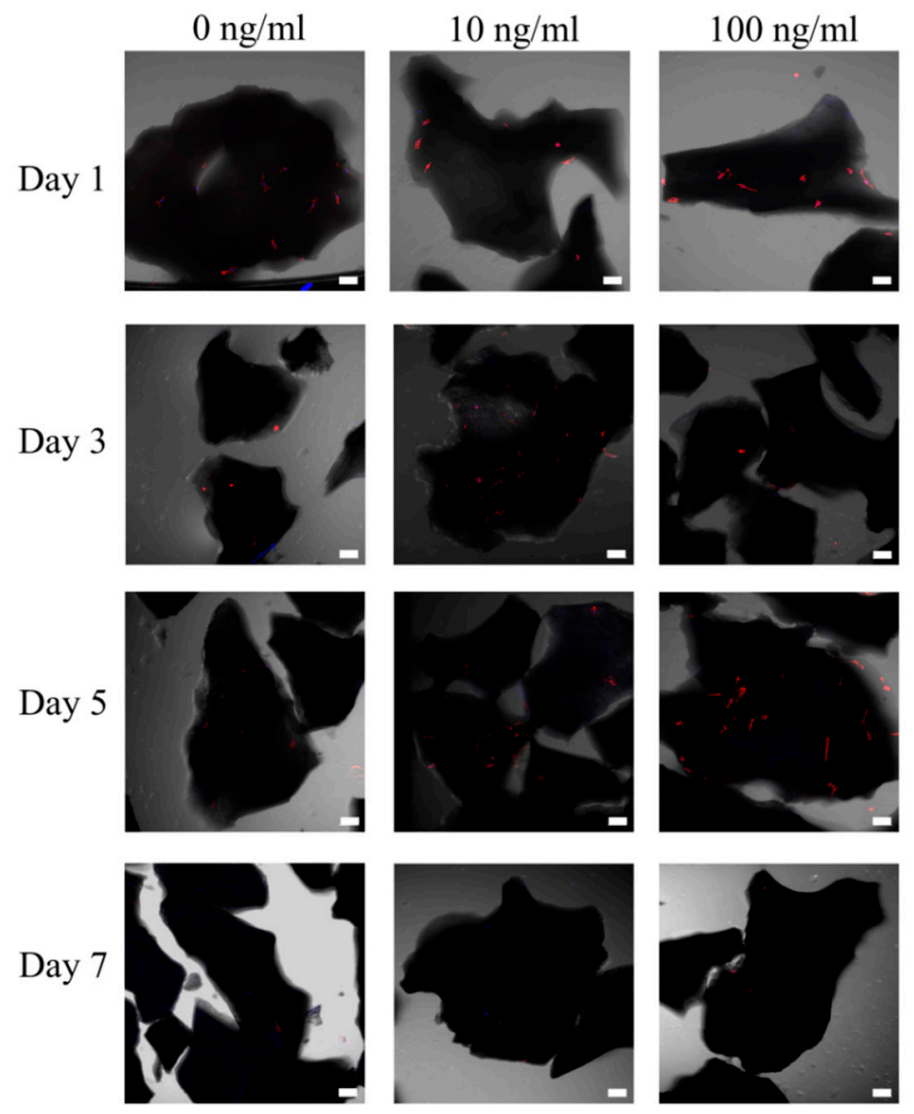

Figure 2. Morphologic characteristics of stem cells loaded on the bone mineral particle on Day 1, 3, 5, and 7. Scale bar indicates $100 \mu \mathrm{m}$ (original magnification: $\times 50$ ).

We noticed that most of the stem cells produced a high intensity of green fluorescence, meaning these were live cells (Figure 3). Low or minimal red fluorescence was noted. We did not see any noticeable changes with the longer incubation time on Day 7. 


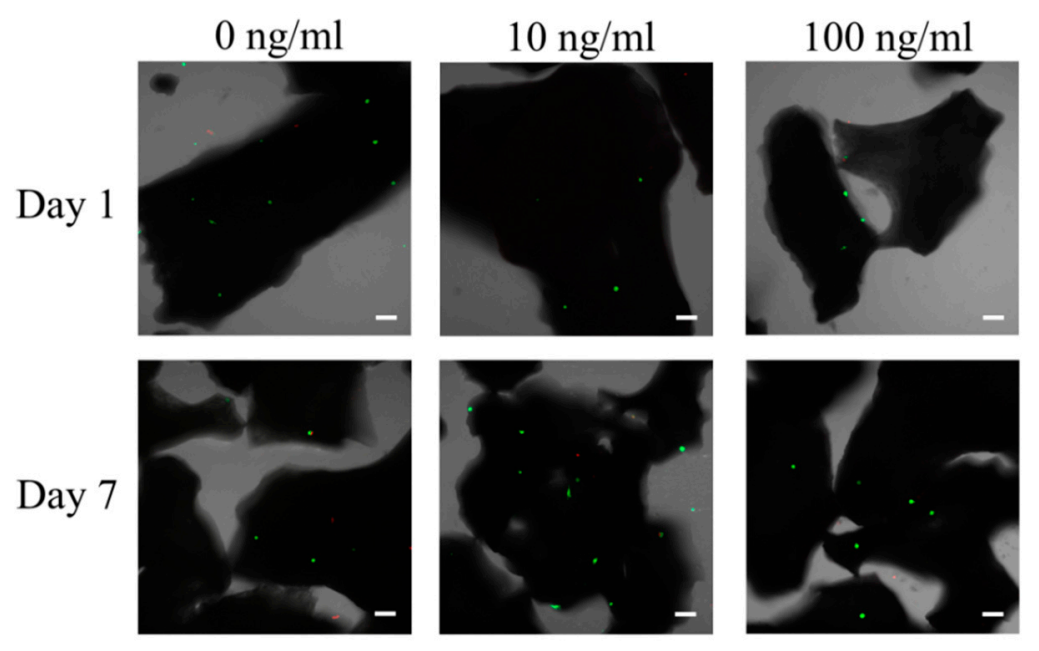

Figure 3. Live, dead, and merged images of stem cells on Days 1 and 7 Scale bar indicates $100 \mu \mathrm{m}$ (original magnification: $\times 50$ ).

Figure 4 shows the absorbance values at $450 \mathrm{~nm}$ on Days 1,3,5, and 7. The results for cellular viability assay values for the IGF-2 groups at 0,10 , and $100 \mathrm{ng} / \mathrm{mL}$ on Day 1 were $0.419 \pm 0.015$, $0.427 \pm 0.013$, and $0.500 \pm 0.030$, respectively $(p<0.05)$.

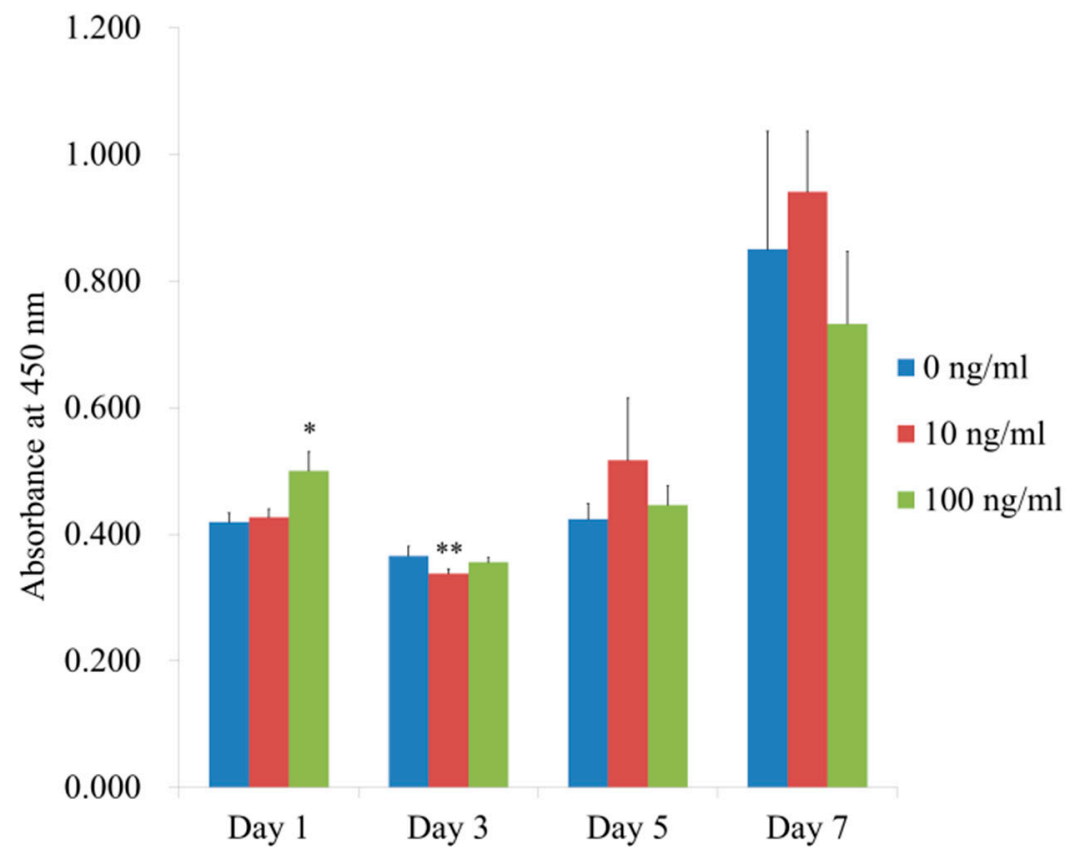

Figure 4. Cellular viability using Cell Counting Kit-8 on Days 1, 3, 5, and 7. * Significant differences were seen when compared to the control at Day $1(p<0.05)$. ${ }^{* *}$ Significant differences were identified when the value was compared to the control at Day $3(p<0.05)$.

\subsection{Level of Osteogenic Differentiation and Mineralization}

Figure 5 shows the results of the alkaline phosphatase activity assays. The absorbance values on Day 7 were $2.112 \pm 0.152,1.897 \pm 0.144$, and $2.067 \pm 0.128$, for IGF- 2 at 0,10 , and $100 \mathrm{ng} / \mathrm{mL}$, respectively $(p>0.05)$. The values at $405 \mathrm{~nm}$ on Day 14 were $2.332 \pm 0.091,2.403 \pm 0.145$, and $2.488 \pm 0.030$, for IGF-2 at 0,10 , and $100 \mathrm{ng} / \mathrm{mL}$, respectively $(p>0.05)$. 


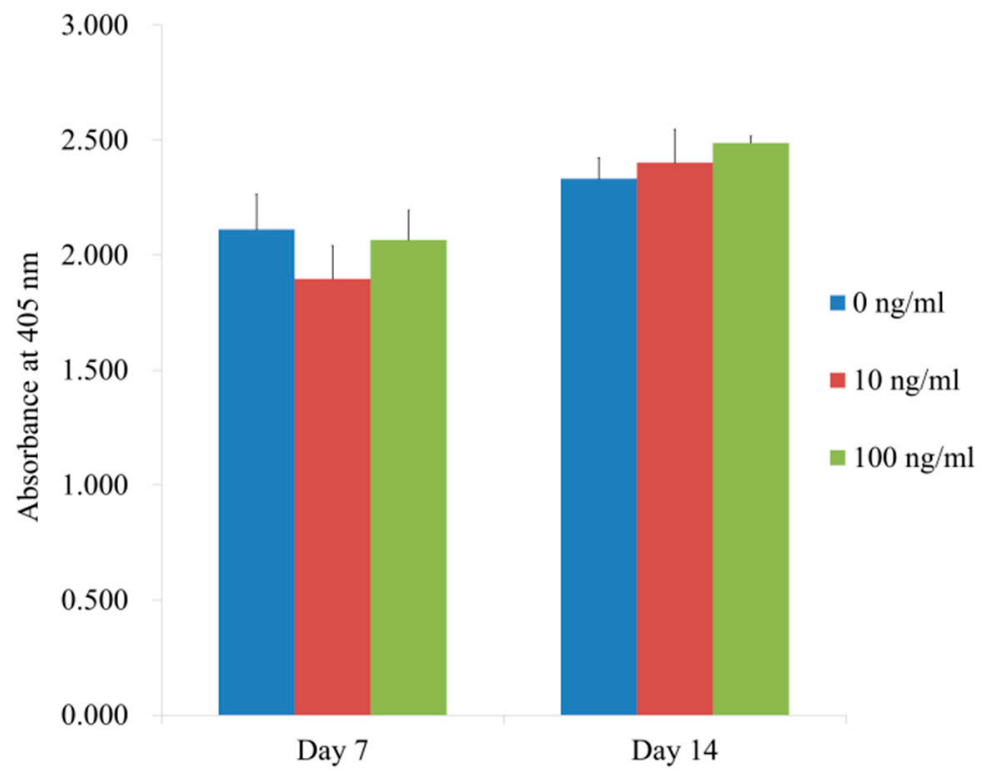

Figure 5. Alkaline phosphatase activity on Days 7 and 14.

Figure 6 shows the results of the mineralization assay at Days 7 and 14. The absorbance values at $560 \mathrm{~nm}$ on Day 7 for IGF-2 at 0, 10, and $100 \mathrm{ng} / \mathrm{mL}$ were $0.497 \pm 0.017,0.801 \pm 0.073$, and $0.690 \pm 0.028$, respectively $(p<0.05)$. The quantification results showed significantly higher values for IGF-2 groups at $10 \mathrm{ng} / \mathrm{mL}$ and $100 \mathrm{ng} / \mathrm{mL}$ concentration when compared with the control $(p<0.05)$. The absorbance values at $560 \mathrm{~nm}$ on Day 14 for IGF-2 at 0,10 , and $100 \mathrm{ng} / \mathrm{mL}$ were $1.322 \pm 0.077,1.408 \pm 0.159$, and $1.353 \pm 0.097$, respectively $(p>0.05)$.

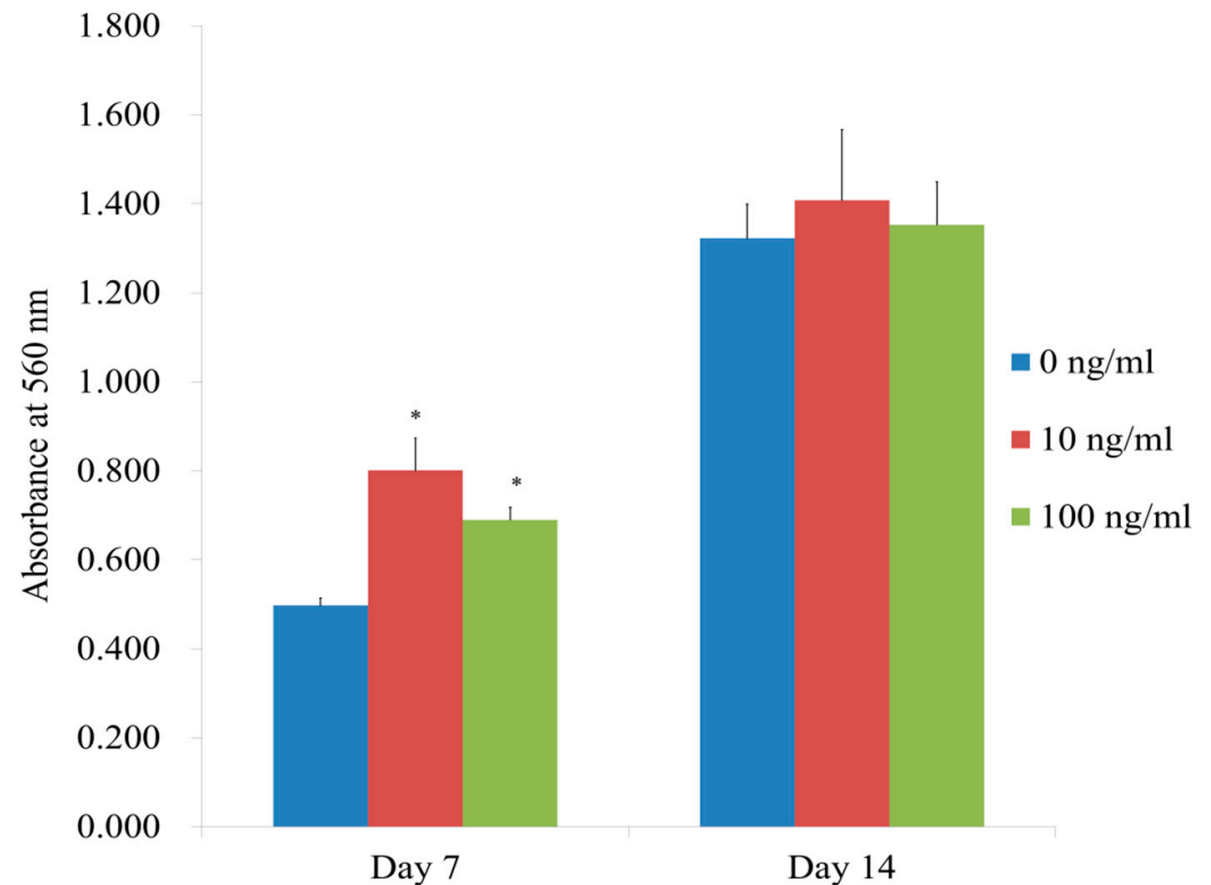

Figure 6. Results of Alizarin Red S staining on Days 7 and 14. * Significant differences were seen when compared to the control at Day $7(p<0.05)$. 
3.3. Total RNA Extraction and Quantification by Real-Time Polymerase Chain Reaction

Quantitative real-time PCR revealed that the mRNA levels of BGLAP were $1.000 \pm 0.022$, $2.016 \pm 0.011$, and $1.429 \pm 0.059$ for IGF-2 groups at 0,10 , and $100 \mathrm{ng} / \mathrm{mL}$, respectively. The results showed that the application of IGF-2 groups of 10 and $100 \mathrm{ng} / \mathrm{mL}$ produced a significant increase of BGLAP (Figure 7A).

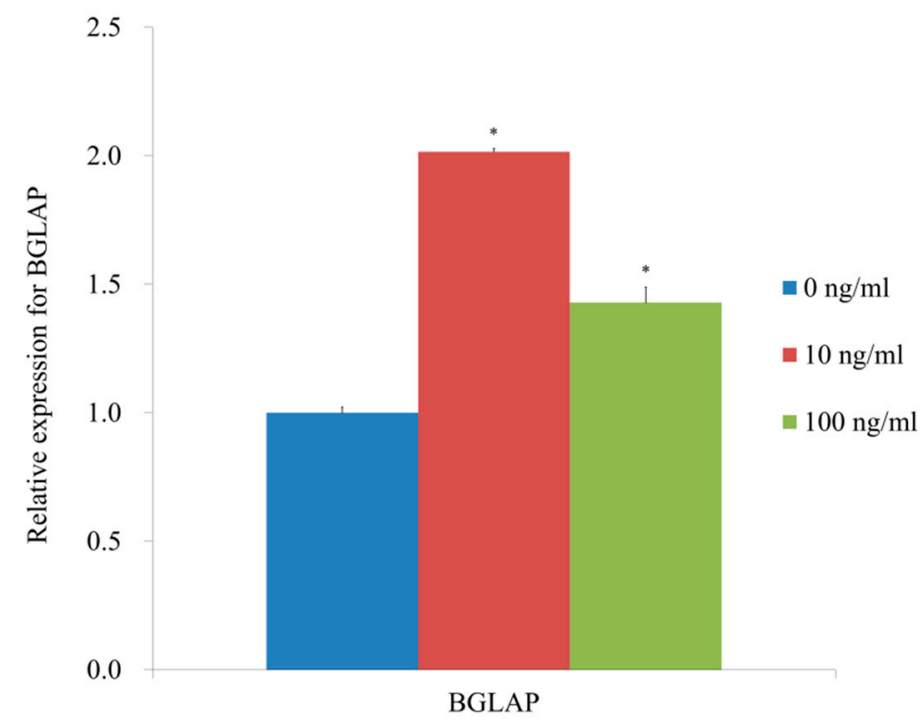

(A) Expression of bone gamma-carboxyglutamate protein (BGLAP)

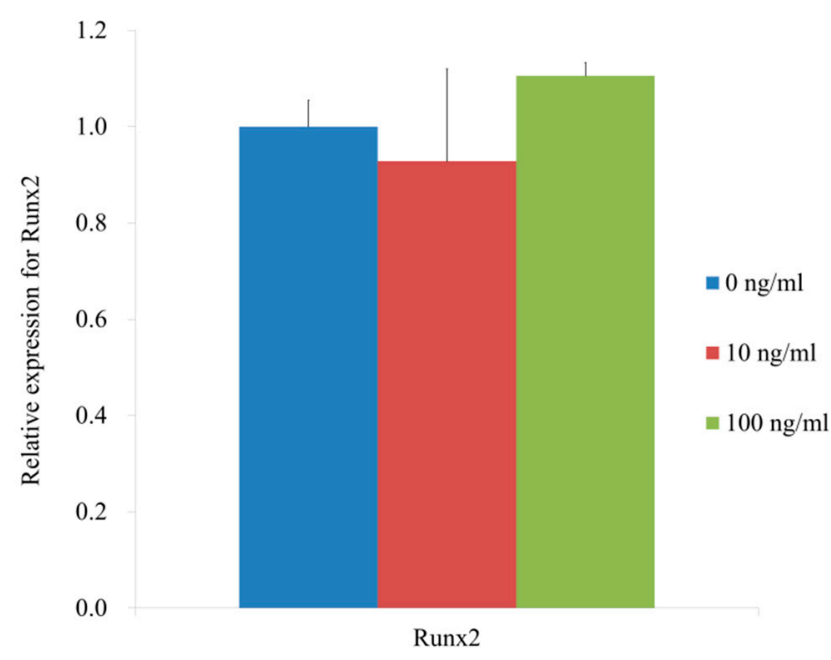

(B) Expression of Runx2

Figure 7. Quantification by real-time polymerase chain reaction. * Statistically significant increase was seen when compared with $0 \mathrm{ng} / \mathrm{mL}$ at Day $7(p<0.05)$.

Quantitative real-time PCR revealed that mRNA levels of Runx2 were $1.000 \pm 0.054,0.928 \pm 0.192$, and $1.106 \pm 0.027$ for IGF-2 groups at 0,10 , and $100 \mathrm{ng} / \mathrm{mL}$, respectively. The results showed that the application of IGF-2 did not produce a significant change in Runx2 expressions (Figure 7B).

\section{Discussion}

In this report, we evaluated the effects of IGF-2 on stem cells that were cultured on deproteinized bovine bone at the concentration of 10 and $100 \mathrm{ng} / \mathrm{mL}$. Applying IGF-2 increased alkaline phosphatase 
activity and mineralization of the bone marrow derived stem cells by enhancing the expression of BGLAP.

IGFs are protein hormones that share structural similarity to insulin, having affinity and specificity to IGF receptors and IGF-binding proteins [18]. IGF-1 is reported to be one of the most abundant growth factors in the bone matrix and it is involved in the maintenance of bone mass in adulthood [19]. In a previous report, IGF-1 promoted the osteogenic differentiation of stem cells and it was suggested that IGF-1 treated stem cells may serve as a candidate for bone regeneration [19]. Alternately, IGF-2 is reported to be involved in the development and function of various organs, including liver and brain [20,21]. IGF-2 is reported to be involved in reversing or preventing the aging-related memory loss in animal model [20]. IGF-2 also acted as an important mitogen regarding liver repopulation in animal model [21]. IGF-2 was reported to be at higher level in the osteoblast-conditioned medium when compared with the control medium conditioned with the stem cells [22]. The expression of IGF-2 in developing osteophyte was strongly associated with a degree of osteogenesis, with the highest expression in active osteoblasts [23]. IGF-2 was shown to produce the increase in the total protein synthesis and collagenous protein synthesis in osteoblast like cells isolated from human bone [24]. Moreover, IGF-2 is reported to be an essential component of stem cell niche and to be involved in the sproliferation and differentiation of stem cells [16]. In this study, the use of IGF-2 on stem cell loaded graft produced higher cellular viability and higher mineralization.

The various concentrations of IGF-2 were tested to evaluate/suggest the optimal concentration $[16,25]$. IGF-2 was used at different concentrations and concentrations ranging from 50 to $200 \mathrm{ng} / \mathrm{mL}$ promoted the proliferation of stem cells [16]. The application of IGF-2 at $200 \mathrm{ng} / \mathrm{mL}$ concentration enhanced the cellular proliferation of human marrow stromal cell line, which was shown by increased $\left[{ }^{3} \mathrm{H}\right]$ thymidine incorporation and increase in the cell number [25]. In this study, the significant increase of osteogenesis and mRNA expression was seen both at 10 and $100 \mathrm{ng} / \mathrm{mL}$, with the highest at $10 \mathrm{ng} / \mathrm{mL}$ concentration. It was shown that IGF-2 had no effects on cell proliferation in the presence of $10 \%$ fetal bovine serum, but it promoted the cellular proliferation in the presence $1 \%$ fetal bovine serum [16]. It was shown that IGF-2 promoted the adipogenic differentiation of stem cells at $100 \mathrm{ng} / \mathrm{mL}$ concentration [26]. Likewise, the net effects or optimal dosage may differ between the studies due to culturing conditions, type, and passages of cells [27]. Moreover, IGF-2 may have additional functions. It was shown that IGF-2 promoted the adipogenic differentiation of stem cells at $100 \mathrm{ng} / \mathrm{mL}$ concentration [26]. IGFs have been shown to be involved in the chondrogenesis and the addition of IGF-2 increased the induction of chondrogenic differentiation while using the three-dimensional culture system [28,29].

The expressions of various genes were tested to evaluate the osteogenic differentiation including Runx 2 and BGLAP [17,30]. Runx2 and BGLAP are widely used biomarkers for osteogenic differentiation [30]. BGLAP was reported to play an important role in the modulation of osteogenic differentiation of mesenchymal stem cells and the maturation of mineral species [31]. In a previous report, attempts were made to achieve the increase in osteogenic potential of stem cells by applying hypoxic conditions [32]. Hypoxia condition upregulation of the various genes, including BGLAP and SPP1, but the condition did not affect Runx2 expression [32]. In this report, IGF-2 seems to enhance the expression of BGLAP without influencing the expression of Runx2.

\section{Conclusions}

Collectively, these results showed that the application of IGF-2 on stem cell loaded bone graft increased cellular viability, Alizarin red staining, and BGLAP expression of stem cells. This report suggests that the combined approach of stem cells and IGF-2 with scaffold may have synergistic effects on osteogenesis. 
Author Contributions: Conceptualization, H.L., S.K.M., Y.-H.P. and J.-B.P.; methodology, H.L., S.K.M., Y.-H.P. and J.-B.P.; formal analysis, H.L., S.K.M., Y.-H.P. and J.-B.P.; writing-original draft preparation, H.L., S.K.M., Y.-H.P. and J.-B.P.; and writing-review and editing, H.L., S.K.M., Y.-H.P. and J.-B.P. All authors have read and agreed to the published version of the manuscript.

Funding: This study was funded by the National Research Foundation of Korea (NRF) grant funded by the Korea government (MSIT) (No. 2020R1A2C4001624). This research was also funded by Research Fund of Seoul St. Mary's Hospital, The Catholic University of Korea.

Acknowledgments: The Catholic MASTER Cells were derived from human bone marrow donated by healthy donors after informed consent and the Catholic MASTER Cells were supplied by CIC.

Conflicts of Interest: The authors report no conflicts of interest.

\section{References}

1. Park, J.B. Clinical and histomorphometric evaluation of staged approach using bone augmentation and autogenous masticatory mucosal graft with endosseous implant placement: A case report. J. Oral Implantol. 2008, 34, 334-338. [CrossRef]

2. Park, J.B. Implant installation with simultaneous ridge augmentation. Report of three cases. J. Oral Implantol. 2011, 37, 595-603. [CrossRef] [PubMed]

3. Ge, Y.; Feng, H.; Wang, L. Application of a novel resorbable membrane in the treatment of calvarial defects in rats. J. Biomater. Sci. Polym. Ed. 2011, 22, 2417-2429. [CrossRef] [PubMed]

4. de Fernandez Grado, G.; Keller, L.; Idoux-Gillet, Y.; Wagner, Q.; Musset, A.M.; Benkirane-Jessel, N.; Bornert, F.; Offner, D. Bone substitutes: A review of their characteristics, clinical use, and perspectives for large bone defects management. J. Tissue Eng. 2018, 9. [CrossRef] [PubMed]

5. Park, J.B. Healing of extraction socket grafted with deproteinized bovine bone and acellular dermal matrix: Histomorphometric evaluation. Implant. Dent. 2010, 19, 307-313. [CrossRef]

6. Kang, S.H.; Park, J.B.; Kim, I.; Lee, W.; Kim, H. Assessment of stem cell viability in the initial healing period in rabbits with a cranial bone defect according to the type and form of scaffold. J. Periodontal Implant. Sci. 2019, 49, 258-267. [CrossRef]

7. Maglione, M.; Salvador, E.; Ruaro, M.E.; Melato, M.; Tromba, G.; Angerame, D.; Bevilacqua, L. Bone regeneration with adipose derived stem cells in a rabbit model. J. Biomed. Res. 2018, 33, $38-45$. [CrossRef]

8. Park, J.B. Use of cell-based approaches in maxillary sinus augmentation procedures. J. Craniofac. Surg. 2010, 21, 557-560. [CrossRef]

9. Park, K.H.; Kim, H.; Moon, S.; Na, K. Bone morphogenic protein-2 (BMP-2) loaded nanoparticles mixed with human mesenchymal stem cell in fibrin hydrogel for bone tissue engineering. J. Biosci. Bioeng. 2009, 108, 530-537. [CrossRef]

10. Park, J.B.; Kim, K.Y.; Lee, W.; Kim, H.; Kim, I. Combinatorial effect of stem cells derived from mandible and recombinant human bone morphogenetic protein-2. Tissue Eng. Regen. Med. 2015, 12, 343-351. [CrossRef]

11. Kawai, M.; Rosen, C.J. The insulin-like growth factor system in bone: Basic and clinical implications. Endocrinol. Metab. Clin. N. Am. 2012, 41, 323-333. [CrossRef] [PubMed]

12. Hill, P.A.; Reynolds, J.J.; Meikle, M.C. Osteoblasts mediate insulin-like growth factor-I and -II stimulation of osteoclast formation and function. Endocrinology 1995, 136, 124-131. [CrossRef]

13. Chen, L.; Jiang, W.; Huang, J.; He, B.C.; Zuo, G.W.; Zhang, W.; Luo, Q.; Shi, Q.; Zhang, B.Q.; Wagner, E.R.; et al. Insulin-like growth factor 2 (IGF-2) potentiates BMP-9-induced osteogenic differentiation and bone formation. J. Bone Miner. Res. Off. J. Am. Soc. Bone Miner. Res. 2010, 25, 2447-2459. [CrossRef] [PubMed]

14. Jeong, C.H.; Kim, S.M.; Lim, J.Y.; Ryu, C.H.; Jun, J.A.; Jeun, S.S. Mesenchymal stem cells expressing brain-derived neurotrophic factor enhance endogenous neurogenesis in an ischemic stroke model. BioMed Res. Int. 2014, 2014, 129145. [CrossRef]

15. Tae, J.Y.; Ko, Y.; Park, J.B. Evaluation of fibroblast growth factor-2 on the proliferation of osteogenic potential and protein expression of stem cell spheroids composed of stem cells derived from bone marrow. Exp. Ther. Med. 2019, 18, 326-331. [CrossRef] [PubMed]

16. Wang, C.; Li, X.; Dang, H.; Liu, P.; Zhang, B.O.; Xu, F. Insulin-like growth factor 2 regulates the proliferation and differentiation of rat adipose-derived stromal cells via IGF-1R and IR. Cytotherapy 2019, 21, 619-630. [CrossRef] 
17. Lee, H.; Lee, H.; Na, C.B.; Park, J.B. The effects of simvastatin on cellular viability, stemness and osteogenic differentiation using 3-dimensional cultures of stem cells and osteoblast-like cells. Adv. Clin. Exp. Med. Off. Organ Wroc. Med. Univ. 2019, 28, 699-706. [CrossRef]

18. Cohen, P.; Peehl, D.M.; Lamson, G.; Rosenfeld, R.G. Insulin-like growth factors (IGFs), IGF receptors, and IGF-binding proteins in primary cultures of prostate epithelial cells. J. Clin. Endocrinol. Metab. 1991, 73, 401-407. [CrossRef]

19. Wang, S.; Mu, J.; Fan, Z.; Yu, Y.; Yan, M.; Lei, G.; Tang, C.; Wang, Z.; Zheng, Y.; Yu, J.; et al. Insulin-like growth factor 1 can promote the osteogenic differentiation and osteogenesis of stem cells from apical papilla. Stem Cell Res. 2012, 8, 346-356. [CrossRef]

20. Steinmetz, A.B.; Johnson, S.A.; Iannitelli, D.E.; Pollonini, G.; Alberini, C.M. Insulin-like growth factor 2 rescues aging-related memory loss in rats. Neurobiol. Aging 2016, 44, 9-21. [CrossRef]

21. Wang, M.J.; Chen, F.; Liu, Q.G.; Liu, C.C.; Yao, H.; Yu, B.; Zhang, H.B.; Yan, H.X.; Ye, Y.; Chen, T.; et al. Insulin-like growth factor 2 is a key mitogen driving liver repopulation in mice. Cell Death Dis. 2018, 9, 26. [CrossRef] [PubMed]

22. Abu-Khader, A.; Law, K.W.; Jahan, S.; Manesia, J.K.; Pasha, R.; Hovey, O.; Pineault, N. Paracrine Factors Released by Osteoblasts Provide Strong Platelet Engraftment Properties. Stem Cells 2019, 37, 345-356. [CrossRef] [PubMed]

23. Middleton, J.; Arnott, N.; Walsh, S.; Beresford, J. Osteoblasts and osteoclasts in adult human osteophyte tissue express the mRNAs for insulin-like growth factors I and II and the type 1 IGF receptor. Bone 1995, 16, 287-293. [CrossRef]

24. Strong, D.D.; Beachler, A.L.; Wergedal, J.E.; Linkhart, T.A. Insulinlike growth factor II and transforming growth factor beta regulate collagen expression in human osteoblastlike cells in vitro. J. Bone Miner. Res. Off. J. Am. Soc. Bone Miner. Res. 1991, 6, 15-23. [CrossRef]

25. Thomas, T.; Gori, F.; Spelsberg, T.C.; Khosla, S.; Riggs, B.L.; Conover, C.A. Response of bipotential human marrow stromal cells to insulin-like growth factors: Effect on binding protein production, proliferation, and commitment to osteoblasts and adipocytes. Endocrinology 1999, 140, 5036-5044. [CrossRef]

26. Zhang, K.; Wang, F.; Huang, J.; Lou, Y.; Xie, J.; Li, H.; Cao, D.; Huang, X. Insulin-like growth factor 2 promotes the adipogenesis of hemangioma-derived stem cells. Exp. Ther. Med. 2019, 17, 1663-1669. [CrossRef]

27. Yu, N.H.; Chun, S.Y.; Ha, Y.S.; Kim, H.T.; Kim, D.H.; Kim, J.; Chung, J.W.; Lee, J.N.; Song, P.H.; Yoo, E.S.; et al. Optimal Stem Cell Transporting Conditions to Maintain Cell Viability and Characteristics. Tissue Eng. Regen. Med. 2018, 15, 639-647. [CrossRef]

28. Longobardi, L.; O’Rear, L.; Aakula, S.; Johnstone, B.; Shimer, K.; Chytil, A.; Horton, W.A.; Moses, H.L.; Spagnoli, A. Effect of IGF-I in the chondrogenesis of bone marrow mesenchymal stem cells in the presence or absence of TGF-beta signaling. J. Bone Miner. Res. Off. J. Am. Soc. Bone Miner. Res. 2006, 21, 626-636. [CrossRef]

29. Youssef, A.; Aboalola, D.; Han, V.K. The Roles of Insulin-Like Growth Factors in Mesenchymal Stem Cell Niche. Stem Cells Int. 2017, 2017, 9453108. [CrossRef]

30. Lv, H.; Yang, H.; Wang, Y. Effects of miR-103 by negatively regulating SATB2 on proliferation and osteogenic differentiation of human bone marrow mesenchymal stem cells. PLoS ONE 2020, 15, e0232695. [CrossRef]

31. Tsao, Y.T.; Huang, Y.J.; Wu, H.H.; Liu, Y.A.; Liu, Y.S.; Lee, O.K. Osteocalcin Mediates Biomineralization during Osteogenic Maturation in Human Mesenchymal Stromal Cells. Int. J. Mol. Sci. 2017, 18, 159. [CrossRef] [PubMed]

32. Fernandez-Moure, J.S.; Corradetti, B.; Chan, P.; Van Eps, J.L.; Janecek, T.; Rameshwar, P.; Weiner, B.K.; Tasciotti, E. Enhanced osteogenic potential of mesenchymal stem cells from cortical bone: A comparative analysis. Stem Cell Res. Ther. 2015, 6, 203. [CrossRef] [PubMed]

(C) 2020 by the authors. Licensee MDPI, Basel, Switzerland. This article is an open access article distributed under the terms and conditions of the Creative Commons Attribution (CC BY) license (http://creativecommons.org/licenses/by/4.0/). 